\title{
DETERMINAN PERMINTAAN PEMBIAYAAN SYARIAH DETERMINAN PERMINTAAN PETANI KELAPA SAWIT TERHADAP PEMBIAYAAN SYARIAH
}

\author{
Henny Indrawati \\ Pendidikan Ekonomi FKIP Universitas Riau \\ Kampus Binawidya, km.12,5 Panam, Pekanbaru \\ Email:pku_henny@yahoo.com
}

\begin{abstract}
ABSTRAK. Kelapa sawit merupakan salah satu komoditas unggulan sektor perkebunan Provinsi Riau umumnya, dan Kabupaten Kampar khususnya. Oleh karena itu perkebunan kelapa sawit perlu dikembangkan, sehingga diperlukan peran petani di dalamnya. Salah satu faktor essensial yang diperlukan petani dalam mengembangkan kebun kelapa sawitnya adalah permodalan. Masalah yang muncul adalah sebagian besar petani tidak sanggup mendanai usahatani yang padat modal dengan dana sendiri. Oleh karena itu diperlukan sumber dana yang berasal dari luar petani. Salah satu sumber dana tersebut berasal dari bank syariah berupa pembiayaan syariah. Penelitian ini bertujuan mengetahui pengaruh faktor internal dan faktor eksternal petani dalam menentukan permintaan petani terhadap pembiayaan syariah. Penelitian ini menggunakan metode survei. Sampel penelitian adalah petani kelapa sawit Kabupaten Kampar yang menjadi debitur pembiayaan syariah di Bank Riau Syariah. Pendekatan analisis yang digunakan adalah analisis SEM (Structural Equation Modelling) dengan metode PLS (Partial Least Square) menggunakan software Smart PLS. Hasil penelitian menunjukkan: Pertama, Faktor internal petani berpengaruh dalam menentukan permintaan petani terhadap pembiayaan syariah. Faktor internal petani yang berperan paling besar dalam menentukan permintaan petani terhadap pembiayaan syariah adalah sikap petani terhadap pembiayaan syariah; Kedua, Faktor eksternal petani berpengaruh dalam menentukan permintaan petani terhadap pembiayaan syariah. Faktor eksternal petani yang berperan paling besar dalam menentukan permintaan petani terhadap pembiayaan syariah adalah profesionalisme pegawai bank syariah.
\end{abstract}

Kata kunci : Faktor Internal Petani, Faktor Eksternal Petani, Permintaan Petani terhadap Pembiayaan Syariah

\section{THE DEMAND DETERMINANTS OF PALM OIL FARMERS FOR SHARIA FINANCING}

ABSTRACT. Palm oil is one of the most primary commodities in the Riau province's plantation, especially in the Kampar district. Therefore, the palm oil plantation is needed to be established. This establishment will be related to mostly on the role of the palm oil farmers. One of the essential factors that are needed by the farmers in order to develop their palm oil plantation is to reach the optimum results in the use and the requirement of capital. The problems were most of farmers can't finance their businsess by their self. The farmers need the capital source from the outside. One of the capital sources for is the sharia financing. This study aims to knowing the impact of the internal and external factors of the palm oil farmers in determining the farmers' demand towards the sharia financing. A survey method was applied. The samples consist of palm oil farmers in Kampar district who are the debtor of Riau Sharia Bank. The data was collected by using questioners through interview, and field observation. The data were analyzed by SEM (Structural Equation Modeling) and by using PLS (Partial Least Square) method with Smart PLS software. The results indicated that firstly, the farmers' internal factors influential in determining the demand of sharia financing. The farmers' internal factors that contribute to the most farmers in determining the demand for sharia financing was the attitudes towards sharia financing; Secondly, the farmers' external factors were important in determining the demand of sharia financing. The farmers' external factors that contribute to the most farmers related to the professionalism of bank employee.

Keywords: farmers' internal factors, farmers' external factors, farmers' demand of sharia financing

\section{PENDAHULUAN}

Kelapa sawit merupakan salah satu tanaman perdagangan yang cukup potensial di Provinsi Riau. Almasdi (2003) menyatakan bahwa kelapa sawit ditetapkan oleh Pemerintah Provinsi Riau sebagai komoditas unggulan daerah. Hampir semua kabupaten di Provinsi Riau memiliki perkebunan kelapa sawit. Untuk jelasnya, dapat dilihat pada Tabel 1. Dari Tabel 1 terlihat Kabupaten Kampar memiliki luas areal kelapa sawit terluas dan produksi terbesar bila dibandingkan dengan kabupaten/kota lainnya di Provinsi Riau, yaitu $413.933 \mathrm{Ha}$ (18,34 persen) dan 1.157 .868 ton $(17,70$ persen). Hal ini berarti kelapa sawit merupakan komoditas unggulan Kabupaten
Kampar. Oleh karena itu harus dikembangkan agar kontribusinya dalam perekonomian daerah Riau semakin meningkat.

\begin{tabular}{llrrrrr}
\hline & & \multicolumn{2}{c}{ Luas Areal } & \multicolumn{2}{c}{ Produksi } \\
\cline { 4 - 7 } No. & Kabupaten/Kota & \multicolumn{1}{c}{ Ha } & \multicolumn{1}{c}{ Ton } & \multicolumn{1}{c}{$\%$} \\
\hline 1 & Kuantan Singingi & 123.512 & 5,47 & 412.913 & 5,96 \\
2 & Indragiri Hulu & 118.970 & 5,27 & 393.991 & 5,68 \\
3 & Indragiri Hilir & 226.398 & & 10 & 678.670 & 9,79 \\
4 & Pelalawan & 304.052 & & 13,5 & 1.142 .395 & 16,5 \\
5 & Siak & 237.043 & 10,5 & 738.879 & 10,7 \\
6 & Kampar & 413.933 & 18,3 & 1.157 .868 & 16,7 \\
7 & Rokan Hulu & 362.756 & $16,11.036 .646$ & 15 \\
8 & Bengkalis & 177.169 & 7,85 & 436.411 & 6,3 \\
9 & Rokan Hilir & 247.970 & 11 & 829.094 & 12 \\
10 & Pekanbaru & - & - & - & - \\
11 & Dumai & 10.732 & 0,48 & 30.581 & 0,44 \\
& Jumlah & 2.256 .538 & 1006.932 .572 & 100 \\
\hline
\end{tabular}

Sumber: Riau dalam Angka, 2012.

Tabel 1. Keadaan Luas Areal dan Produksi Kelapa Sawit di Provinsi Riau Tahun 2011 
Petani berperan penting dalam pengembangan perkebunan kelapa sawit. Kesulitan para petani dalam memperoleh akses sumber modal menjadi kendala dalam pengembangan perkebunan kelapa sawit. Adanya asas prudential banking (prinsip kehatihatian) yang dianut oleh bank tentu menyebabkan petani sulit memperoleh pinjaman modal, ditambah lagi kemampuan manajerial petani yang masih minim.

Masalah lain yang juga muncul adalah petani tidak sanggup membiayai usahatani yang padat modal dengan dana sendiri, sehingga diperlukan sumber dana yang berasal dari eksternal petani. Salah satu sumbernya berasal dari bank syariah berupa pembiayaan syariah. Lembaga perbankan syariah di Provinsi Riau yang paling banyak memberikan pembiayaan untuk perkebunan kelapa sawit adalah Bank Riau Syariah.

Bank Riau Syariah menyalurkan pembiayaan secara individu dan secara kolektif kepada petani melalui KUD. Sampai akhir tahun 2011, Bank Riau Syariah telah menyalurkan pembiayaan sebesar Rp225 miliar bagi nasabah yang membutuhkan pembiayaan baik untuk perkebunan kelapa sawit maupun sektor lainnya. Trend pembiayaan Bank Riau Syariah terus mengalami peningkatan. Pada pertengahan tahun 2012, pembiayaan yang tercatat sekitar Rp257 miliar. Namun peningkatan yang terjadi bukan peningkatan pembiayaan bagi petani kelapa sawit, melainkan pembiayaan bagi pelaku usaha di luar perkebunan kelapa sawit (Bank Riau Syariah, 2012). Hal ini menunjukkan masih banyak petani kelapa sawit yang belum memperoleh pembiayaan dari Bank Riau Syariah.

Ada beberapa kemungkinan penyebabnya, baik berasal dari faktor internal maupun faktor eksternal petani. Diantaranya adalah tingkat pendapatan petani yang kurang mencukupi untuk membayar angsuran pembiayaan, kurangnya sosialisasi yang dilakukan pihak Bank Riau Syariah, persyaratan yang diminta oleh Bank Riau Syariah tidak dapat dipenuhi, atau prosedur pembiayaan yang mungkin dirasakan petani berbelit-belit. Sehubungan dengan hal itu, maka perlu dilakukan pengkajian yang lebih mendalam guna mendapatkan jawaban yang lebih akurat mengenai faktor apa yang menentukan permintaan petani kelapa sawit terhadap pembiayaan syariah.

Tujuan penelitian ini secara umum adalah untuk mengkaji dan menganalisis determinan permintaan petani kelapa sawit terhadap pembiayaan syariah. Tujuan penelitian ini secara spesifik adalah untuk mengetahui pengaruh faktor internal dan faktor eksternal petani dalam menentukan permintaan petani terhadap pembiayaan syariah.

\section{METODE}

\section{Objek Penelitian}

Yang menjadi objek penelitian yaitu petani kelapa sawit di Kabupaten Kampar yang menjadi debitur Bank Riau Syariah Cabang Pekanbaru. Populasi seluruh debitur (petani kelapa sawit di Kabupaten Kampar) yang terdaftar per 31 Desember 2010 di Bank
Riau Syariah, berjumlah 1.200 nasabah yang tersebar pada 3 kecamatan di Kabupaten Kampar. Sebarannya adalah 420 orang di Kecamatan Perhentian Raja, 510 orang di Kecamatan Tapung, dan 270 orang di Kecamatan Rumbio Jaya.

\section{Sumber Data dan Cara Menentukannya}

Sumber data yang digunakan meliputi data primer dan data sekunder. Data primer dikumpulkan dari petani kelapa sawit yang mendapatkan pembiayaan syariah dari Bank Riau Syariah. Data dikumpulkan melalui wawancara langsung dengan menggunakan kuesioner. Data sekunder dikumpulkan dari Bank Indonesia Provinsi Riau, Bank Riau Syariah Cabang Pekanbaru, Dinas Perkebunan Provinsi Riau, dan dinas/instansi terkait lainnya.

Mengingat pendekatan yang digunakan untuk analisis data adalah analisis SEM, dan jumlah semua variabel manifest 31 variabel, maka jumlah sampel responden yang sesuai untuk hal tersebut akan ditentukan sebanyak 7 x 31 variabel yaitu 217 sampel responden. Untuk kepraktisan penelitian, maka jumlah sampel ditentukan 220 orang petani.

Sistem penyaluran pembiayaan syariah melalui dua cara yaitu bank bekerjasama dengan KUD (kolektif) dan petani secara individu langsung melakukan peminjaman di Bank Riau Syariah. Selanjutnya sampel penelitian ditentukan dengan menggunakan teknik Proportional Random Sampling. Jumlah sampel petani melalui KUD (kolektif) dan individu untuk masing-masing kecamatan, dapat dilihat pada Tabel 2 .

Tabel 2. Jumlah Sampel Petani Kelapa Sawit yang Menjadi Debitur Pembiayaan Syariah di Bank Riau Syariah (Orang)

\begin{tabular}{llrrr}
\hline No. & Kecamatan & Kolektif & Individu & Jumlah \\
\hline 1. & Perhentian Raja & 54 & 23 & 77 \\
2. & Tapung & 66 & 28 & 94 \\
3. $\quad$ Rumbio Jaya & 34 & 15 & 49 \\
\hline Jumlah & 154 & 66 & 220 \\
\hline
\end{tabular}

Sumber: Bank Riau Syariah, 2011, data diolah.

\section{Alat Analisis Data dan Uji Hipotesis}

Dalam penelitian ini, model dianalisis dengan metode Partial Least Square (PLS) dengan menggunakan software SmartPLS. Penelitian menggunakan analisis 2ndCFA. Untuk tingkat pertama (first order) adalah variabel laten yang terdiri dari kondisi sosial ekonomi petani, pengetahuan petani tentang pembiayaan syariah, sikap petani terhadap pembiayaan syariah, aktivitas sosialisasi pembiayaan syariah, persyaratan pembiayaan syariah, prosedur pemberian pembiayaan syariah, profesionalisme pegawai bank syariah, dan akses terhadap pembiayaan syariah. Untuk tingkat kedua (second order) adalah konstruk faktor internal petani dan faktor eksternal petani. 


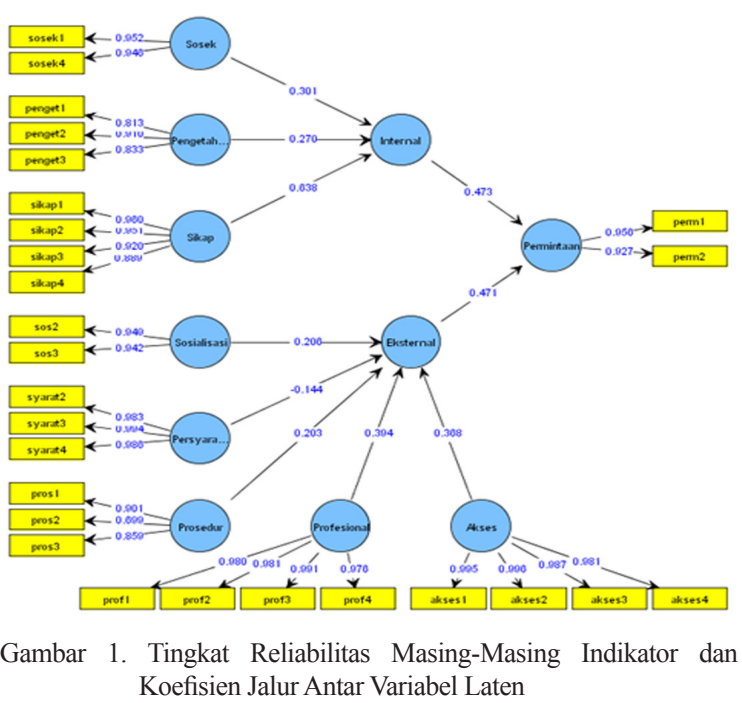

HASIL DAN PEMBAHASAN

Pengaruh Faktor Internal Petani dan Faktor Eksternal Petani dalam Menentukan Permintaan Petani terhadap Pembiayaan Syariah

Sebagaimana yang telah dijelaskan sebelumnya, untuk menganalisis pengaruh faktor internal dan eksternal terhadap permintaan pembiayaan syariah digunakan analisis SEM dengan bantuan software smartpls. Adapun hasilnya dapat dilihat pada Gambar 1.

Pengaruh Faktor Internal Petani secara Parsial dalam Menentukan Permintaan Petani terhadap Pembiayaan Syariah

Hipotesis pertama dalam penelitian ini adalah faktor internal petani berpengaruh dalam menentukan permintaan petani terhadap pembiayaan syariah. Pengujian hipotesis dilakukan dengan membandingkan nilai $t_{\text {hitung }}$ koefisien jalur dengan $t_{\text {tabel }} \alpha 5 \%=1,96$. Dari hasil analisis diperoleh bahwa nilai $t_{\text {hitung }}$ koefisien jalur faktor internal petani terhadap permintaan petani terhadap pembiayaan syariah adalah 3,476 yang lebih besar dari nilai $t_{\text {tabel }}$ 1,96. Hal ini mengindikasikan bahwa $\mathrm{HO}$ ditolak atau hipotesis penelitian diterima, yang berarti bahwa faktor internal petani berpengaruh dalam menentukan permintaan petani terhadap pembiayaan syariah.

Pengaruh Kondisi Sosial Ekonomi Petani dalam Menentukan Permintaan Petani terhadap Pembiayaan Syariah

Kondisi sosial ekonomi petani memberikan pengaruh tidak langsung dalam menentukan permintaan petani terhadap pembiayaan syariah. Besar pengaruhnya 10,12 persen. Petani yang sudah tepat memanfaatkan pembiayaan syariah dan berkeinginan untuk mengambil kembali pembiayaan syariah adalah petani yang memiliki kebun kelapa sawit 6-8 ha, dengan pengalaman berkebun sawit lebih dari 20 tahun dan pendapatan 9-14 juta rupiah dalam satu tahun. Semakin luas kebun kelapa sawit yang dimiliki petani, maka akan semakin besar pula nilai pembiayaan syariah yang bisa diperoleh petani, karena produksi TBS yang diperoleh semakin berat dan banyak sehingga dari hasil penjualan TBS tersebut menghasilkan pendapatan petani yang juga semakin meningkat. Jadi, semakin baik dan kondusif kondisi sosial ekonomi petani, maka semakin memungkinkan petani untuk mendapatkan pembiayaan dari bank syariah sehingga akan meningkatkan permintaan petani terhadap pembiayaan syariah. Perubahan kondisi sosial ekonomi akan direspon secara positif oleh perubahan permintaan petani terhadap pembiayaan syariah.

Fanwell (2004), Oluwasola\&Alimi (2008), Oboh\&Kushwaha (2009) di Nigeria juga menyatakan. Semakin baik karakteristik sosial ekonomi petani, maka permintaan kredit usahatani akan meningkat.

Pengaruh Pengetahuan Petani tentang Pembiayaan Syariah dalam Menentukan Permintaan Petani terhadap Pembiayaan Syariah

Pengetahuan petani tentang pembiayaan syariah memberikan pengaruh tidak langsung dalam menentukan permintaan petani terhadap pembiayaan syariah. Besar pengaruhnya 6,45 persen. Petani memiliki keterbatasan sumber pengetahuan tentang pembiayaan syariah, yaitu dari KUD, tetangga, pihak bank syariah, dan koran saja. Oleh karena itu, dapat dikatakan pengetahuan petani tentang pembiayaan syariah relatif sedikit. Petani hanya mengetahui tentang plafon, persyaratan dan prosedur permbiayaan syariah saja. Namun petani tidak begitu memahami tentang berbagai produk dan mekanisme syariah yang ada pada produk bank syariah tersebut.

Schiffman (2003) menggunakan model perilaku konsumen dalam pengambilan keputusan pembelian suatu produk barang atau jasa. Model tersebut terdiri atas tiga komponen. Salah satu komponennya adalah input yang berupa pengaruh pengetahuan konsumen atas suatu produk barang atau jasa. Rahardjo\&Ali (1996) juga melakukan penelitian terkait dengan pengetahuan kredit. Kendala para petani dalam berhubungan dengan sumber-sumber keuangan resmi diantaranya adalah keterbatasan petani dalam memperoleh pengetahuan tentang proses dan prosedur peminjaman. Sementara itu, Hailuddin (2006) menyatakan pengetahuan kredit merupakan salah satu faktor yang mempengaruhi akses industri kecil manufaktur terhadap perkreditan lembaga keuangan perbankan.

Pengaruh Sikap Petani terhadap Pembiayaan Syariah dalam Menentukan Permintaan Petani terhadap Pembiayaan Syariah

Sikap petani terhadap pembiayaan syariah memberikan pengaruh tidak langsung dalam menentukan permintaan petani terhadap pembiayaan syariah. Besar pengaruhnya 24,41 persen. Petani berkeyakinan pembiayaan syariah penting untuk membantu petani mengembangkan usaha kebun kelapa sawitnya. Petani membutuhkan tambahan modal terutama untuk membeli kebun kelapa sawit baru yang ada di sekitar lokasi kebun kelapa sawit mereka. Apabila 
dengan pembiayaan syariah yang diperoleh petani dapat meningkatkan produksi TBS dan pendapatannya, maka akan semakin besar dukungan sikap petani terhadap pembiayaan syariah. Jika sikap petani cenderung mendukung atau bersikap positif terhadap pembiayaan syariah, maka petani akan merasa mengambil pembiayaan syariah pada saat ini sudah tepat dan akan mengambil pembiayaan kembali pada periode berikutnya.

Hailuddin(2006) dalam penelitiannya menemukan sikap terhadap kredit menentukan akses industri kecil manufaktur terhadap lembaga perbankan. Demikian juga Setio (2010) dan Iman Basuki (2010) yang menemukan bahwa sikap UMKM yang berkaitan dengan religiusitas berpengaruh terhadap permintaan mudharabah. Besar pengaruh masing-masing variabel kondisi sosial ekonomi petani, pengetahuan petani tentang pembiayaan syariah, dan sikap petani terhadap pembiayaan syariah dalam menentukan permintaan petani terhadap pembiayaan syariah dirangkum pada Tabel 3.

Tabel 3. Besar Pengaruh Variabel Kondisi Sosial Ekonomi Petani, Pengetahuan Petani tentang Pembiayaan Syariah, dan Sikap Petani terhadap Pembiayaan Syariah dalam Menentukan Permintaan Petani terhadap Pembiayaan Syariah

\begin{tabular}{clc}
\hline No. & \multicolumn{1}{c}{ Variabel } & $\begin{array}{c}\text { Besar Pengaruh } \\
(\%)\end{array}$ \\
\hline 1. & $\begin{array}{l}\text { Kondisi } \\
\text { Petani }\end{array}$ & Sosial Ekonomi \\
2. & $\begin{array}{l}\text { Pengetahuan Petani tentang } \\
\text { Pembiayaan Syariah }\end{array}$ & 6,45 \\
3. $\begin{array}{l}\text { Sikap Petani terhadap } \\
\text { Pembiayaan Syariah }\end{array}$ & 24,42 \\
\hline \multicolumn{3}{c}{ Total } \\
\hline
\end{tabular}

Sumber: data penelitian diolah.

Berdasarkan Tabel 3 terlihat bahwa sikap petani terhadap pembiayaan syariah mempunyai pengaruh yang paling besar dalam menentukan permintaan petani terhadap permintaan terhadap pembiayaan syariah. Hal ini menunjukkan telah ada keyakinan yang kuat pada diri petani bahwa pembiayaan syariah sangat penting dan diperlukan petani untuk membantu permodalan dalam upaya mengembangkan kebun kelapa sawit mereka.

\section{Pengaruh Faktor Eksternal Petani secara Parsial dalam Menentukan Permintaan Petani terhadap Pembiayaan Syariah}

Hipotesis kedua dalam penelitian ini adalah faktor eksternal petani berpengaruh dalam menentukan permintaan petani terhadap pembiayaan syariah. Pengujian hipotesis dilakukan dengan membandingkan nilai $\mathrm{t}_{\text {hitung }}$ koefisien jalur dengan $\mathrm{t}_{\text {tabel }} \alpha 5 \%=1,96$. Dari hasil analisis diperoleh nilai $t_{\text {hitung }}$ koefisien jalur faktor eksternal petani terhadap permintaan petani terhadap pembiayaan syariah adalah sebesar 3,384 yang lebih besar dari nilai $t_{\text {tabel }} 1,96$. Hal ini mengindikasikan bahwa $\mathrm{H} 0$ ditolak atau hipotesis penelitian diterima, yang berarti bahwa faktor eksternal petani berpengaruh dalam menentukan permintaan petani terhadap pembiayaan syariah.

\section{Pengaruh Aktivitas Sosialisasi yang Dilakukan Pihak Bank Syariah dalam Menentukan Permintaan Petani terhadap Pembiayaan Syariah}

Aktivitas sosialisasi yang dilakukan pihak bank syariah memberikan pengaruh tidak langsung dalam menentukan permintaan petani terhadap pembiayaan syariah. Besar pengaruhnya 7,21 persen. Pembiayaan syariah merupakan pembiayaan yang relatif masih baru bagi petani. Petani baru memanfaatkan pembiayaan syariah ini pada akhir tahun 2007, karena sebelumnya petani memanfaatkan kredit dari bank konvensional seperti BRI. Meskipun intensitas sosialisasi yang dilakukan pihak bank syariah hanya satu kali dalam enam bulan, petani sebenarnya tertarik dengan berbagai produk perbankan syariah dari materi sosialisasi yang diberikan pihak bank syariah. Namun sebagian besar petani belum memahami sistem dan mekanisme dari produk perbankan syariah tersebut.

Ansyori (2010) menyatakan masih banyak nasabah yang belum memahami sistem perbankan syariah. Ketidakpahaman nasabah disebabkan karena kurangnya sosialisasi pihak bank. Akibat dari ketidakpahaman itu akan menyebabkan nasabah mengalami kerugian karena tidak memahami sistem dan mekanisme yang berlaku.

\section{Pengaruh Persyaratan Pembiayaan Syariah dalam Menentukan Permintaan Petani terhadap Pembiayaan Syariah}

Persyaratan pembiayaan syariah memiliki pengaruh tidak langsung dalam menentukan permintaan petani terhadap pembiayaan syariah. Besar pengaruhnya 1,74 persen. Sebelum memanfaatkan pembiayaan syariah, petani sudah memanfaatkan kredit dari bank konvensional. Oleh karena itu, petani sudah terbiasa berhubungan dengan pihak bank konvensional dan terbiasa memenuhi berbagai persyaratan kredit yang ditetapkan oleh bank konvensional. Menurut petani, persyaratan pembiayaan syariah yang ditetapkan oleh bank syariah sama dengan persyaratan kredit yang ditetapkan oleh BRI. Pernyataan petani ini didukung oleh pernyataan Yusak (2009), yang menyatakan persyaratan dan ketentuan yang berlaku di bank adalah sama, baik bank syariah maupun bank konvensional. Ketentuan umum yang berlaku di bank untuk dapat diberikan pembiayaan adalah feasible dan bankable. Persyaratan pembiayaan syariah memberikan peran negatif dalam menentukan permintaan terhadap pembiayaan syariah.

\section{Pengaruh Prosedur Pemberian Pembiayaan Syariah dalam Menentukan Permintaan Petani terhadap Pembiayaan Syariah}

Prosedur pemberian pembiayaan syariah memiliki pengaruh tidak langsung dalam menentukan permintaan petani terhadap pembiayaan syariah. 
Besar pengaruhnya 6,27 persen. Petani sudah terbiasa berhubungan dengan pihak bank konvensional (terutama BRI) dan terbiasa menjalani berbagai prosedur pemberian kredit oleh bank konvensional. Menurut mereka, prosedur pemberian pembiayaan syariah hampir sama dengan prosedur pemberian kredit, yaitu diawali dari pengajuan permohonan beserta persyaratannya, lalu pihak bank melakukan survei ke petani. Bedanya hanya terletak pada akad pembiayaan yang harus dilakukan petani di bank syariah pada saat petani menerima dana pembiayaan syariah.

Hailuddin (2006) juga menyatakan bahwa prosedur pemberian kredit berpengaruh signifikan dalam menentukan akses pengusaha industri kecil manufaktur terhadap lembaga perbankan. Keadaan ini mengindikasikan bahwa waktu pencairan kredit yang relatif lama menjadi kendala bagi pengusaha berkaitan dengan prosedur pemberian kredit.

\section{Pengaruh Profesionalisme Pegawai Bank Syariah dalam Menentukan Permintaan Petani terhadap Pembiayaan Syariah}

Profesionalisme pegawai bank syariah memiliki pengaruhtidaklangsungdalammenentukan permintaan terhadap pembiayaan syariah. Besar pengaruhnya 13,61 persen. Petani mendapatkan pelayanan yang baik dari pegawai bank syariah, dimulai dari kegiatan sosialisasi hingga petani melakukan transaksi di bank syariah. Petani mendapatkan perlakuan yang ramah, bersahabat, dan pegawai bank syariah memberikan respon yang relatif cepat dalam melayani petani. Sebenarnya petani lebih peduli dengan perlakuan yang penuh kekeluargaan dari pihak bank, karena seringkali harga jasa bank tidak menjadi masalah bagi petani. Pelayanan pegawai bank syariah menjadi faktor penting yang menentukan kepuasan petani. Dengan pelayanan yang prima, petani akan merasa diperhatikan dan menganggap bahwa pegawai bank sudah profesional dalam menjalankan tugasnya. Dampaknya, kepuasan atas pelayanan yang diberikan itu akan menumbuhkan dan meningkatkan loyalitas petani.

\section{Pengaruh Akses terhadap Pembiayaan Syariah dalam Menentukan Permintaan Petani terhadap Pembiayaan Syariah}

Akses terhadap pembiayaan syariah memiliki pengaruh tidak langsung dalam menentukan permintaan petani terhadap pembiayaan syariah. Besar pengaruhnya 11,98 persen. Petani tidak kesulitan mengakses pembiayaan dari bank syariah, baik jarak, lama perjalanan, ketersediaan alat transportasi, maupun biaya transportasi yang dikeluarkan untuk mengakses pembiayaan syariah. Di samping itu, biaya transportasi yang dikeluarkan juga dirasakan petani relatif murah dan terjangkau oleh petani.

Besarnya pengaruh masing-masing variabel aktivitas sosialisasi yang dilakukan pihak bank syariah, persyaratan pembiayaan syariah, prosedur pemberian pembiayaan syariah, profesionalisme pegawai bank syariah, dan akses terhadap pembiayaan syariah dalam menentukan permintaan terhadap pembiayaan syariah dirangkum pada Tabel 4.

\begin{tabular}{llc}
\hline No. & \multicolumn{1}{c}{ Variabel } & $\begin{array}{c}\text { Besar Pengaruh } \\
(\%)\end{array}$ \\
\hline 1. & $\begin{array}{l}\text { Aktivitas Sosialisasiyang } \\
\text { dilakukan Pihak Bank }\end{array}$ & 7,21 \\
& $\begin{array}{l}\text { Syariah } \\
\text { Persyaratan Pembiayaan } \\
\text { Syariah }\end{array}$ & 1,74 \\
3. $\begin{array}{l}\text { Prosedur Pemberian } \\
\text { Pembiayaan Syariah } \\
\text { 4. Profesionalisme Pegawai } \\
\text { Bank Syariah }\end{array}$ & 13,61 \\
5. Akses terhadap \\
Pembiayaan Syariah
\end{tabular}

Tabel 4. Besar Pengaruh Variabel Aktivitas Sosialisasi, Persyaratan Pembiayaan Syariah, Prosedur Pemberian Pembiayaan Syariah, Profesionalisme Pegawai Bank Syariah dan Akses terhadap Pembiayaan Syariah dalam Menentukan Permintaan Petani terhadap Pembiayaan Syariah

Tabel 4 memperlihatkan profesionalisme pegawai bank syariah mempunyai pengaruh yang paling besar dalam menentukan permintaan petani terhadap pembiayaan syariah. Oleh karena itu, secara umum keramahan, kemampuan, respon, dan penguasaan pegawai bank syariah harus dipertahankan dan ditingkatkan, karena dalam pemasaran jasa, sumberdaya manusia sangat menentukan seberapa baiknya penyampaian jasa yang ditawarkan.

Seperti pendapat Seth (1997) yang menyatakan "people are a crucial component of bank marketing strategy". Hal yang sama juga dikatakan Zeithaml et al (2003) bahwa "employees are service, employees are the organization in the customer eyes". Pegawai dapat dikatakan sebagai faktor kunci dalam mempengaruhi kualitas pelayanan seperti pendapat Hessket et al (1997) yang menyatakan bahwa perilaku orang-orang yang melakukan kontak dengan konsumen sangat penting dan mempengaruhi kualitas pelayanan dan image perusahaan jasa.

\section{SIMPULAN}

Berdasarkan hasil penelitian dan temuan di lapangan serta analisis data sebagaimana telah diuraikan dalam pembahasan, maka dari hasil kajian dan temuan tersebut dapat ditarik beberapa kesimpulan, yaitu:

Faktor internal dan eksternal petani berpengaruh dalam menentukan permintaan petani terhadap pembiayaan syariah.

Faktor internal petani yang berperan paling besar dalam menentukan permintaan petani terhadap pembiayaan syariah adalah sikap petani terhadap pembiayaan syariah.

Faktor eksternal petani yang berperan paling besar dalam menentukan permintaan petani terhadap pembiayaan syariah adalah profesionalisme pegawai bank syariah.

Sikap petani terhadap pembiayaan syariah menjadi determinan penting dalam menentukan permintaan 
petani terhadap pembiayaan syariah. Pemerintah Kabupaten Kampar dapat menjembatani kebutuhan petani dengan memfasilitasi hubungan mereka dengan pihak bank syariah. Salah satu cara yang bisa dilakukan adalah membentuk lembaga penjamin kredit daerah yang berada di bawah pengawasan Pemerintah Daerah Kabupaten Kampar.

Pihak bank syariah perlu meningkatkan profesionalitas pegawainya, dengan mendidik pegawai secara berkesinambungan, seperti mengadakan pelatihanpelatihan tentang operasionalisasi bank sya $=$ riah, cara memberikan pelayanan yang prima kepada nasabah, ataupun membekali pegawai (terutama bagian pembiayaan) tentang pengetahuan dibidang perkebunan kelapa sawit.

\section{DAFTAR PUSTAKA}

Almasdi Syahza. 2003. Rancangan Model Pemberdayaan Ekonomi Pedesaan Melalui Pembangunan Agroestate Kelapa Sawit di Daerah Riau, dalam Jurnal Ekonomi, Th. VIII/02/ November/2003 (89-93).

Ansyori Abdullah. 2010. Nasabah Bank Syariah Merugi Akibat Kurang Sosialisasi. http:// jakartaindonesiana.wordpress.com/2010/05/07/ nasabah-bank-syariah-mergi-akibat-kurangsosialisasi.

Fanwell, 2004, Determinants and Characteristics of Household Demand for Smallholder Credit in Malawi. http://econpapers.repec.org/paper/ wpawuwpgt/0408001.htm.

Hailuddin. 2006. Faktor Internal dan Eksternal yang Mempengaruhi Akses Industri Kecil Manufaktur terhadap Perkreditan Lembaga Keuangan Perbankan. Disertasi Doktor Ilmu Ekonomi Universitas Padjadjaran Bandung.

Heskett, James L., W. Earl Sasser Jr, dan Leonard A. Schlesinger. 1997. The Service Profit Chain.
USA: The Free Press.

Iman Basuki. 2010. Analisis Permintaan Pembiayaan Murabahah oleh Usaha Mikro, Kecil dan Menengah (UMKM): Studi Kasus pada BMT Kube Karanganyar Sejahtera. http://digilib.uns.ac.id.

Oboh, V.U dan S. Kushwaha. 2009. Sosio-Economic Determinants of Farmers' Loans Size in Benue State, Nigeria. Jurnal Penelitian Ilmu Terapan 5 (4): 354-358, INSInet Publication. http://www. insinet.net.

Oluwasola dan Alimi. 2008. Determinants of Agricultural Credit Demand and Supply among Small-Scale Farmers in Nigeria, Jurnal Outlook on Agriculture Volume 37, Nomor 3, September 2008 pp (185-193), IP Publishing Ltd. http:// www.ingentaconnect.com.

Rahardjo, M. D., dan Ali, F. 1996. Faktor-Faktor Keuangan yang Mempengaruhi Usaha Kecil dan Menengah di Indonesia, Dalam K. James \& N. Akrasanee, Aspek-Aspek Finansial Usaha Kecil dan Menengah: Studi Kasus Asean, (pp. 16-50). Jakarta: LP3ES.

Schiffman, Leon G. 2003. Consumer Behavior. London: Prentice hall.

Seth, Rajeev K. 1997. Marketing of Banking Service. India: Macmillan India Ltd.

Setio Susilo. 2010. Pengaruh Karakteristik dan Perilaku UKM, serta Sistem Pembiayaan terhadap Penyaluran Pembiayaan BNI Syariah. Disertasi Pascasarjana IPB Bogor.

Yusak Laksmana. 2009. Tanya Jawab Cara Mudah Mendapatkan Pembiayaan di Bank Syariah, Jakarta: PT. Elex Media Komputindo.

Zeithaml, Valerie A, dan Mary Jo Bitner. 2003. Service Marketing. International Edition. USA: MC Graw Hill Inc. 